\title{
Urbanization, economic growth and industrial structure on carbon dioxide emissions: empirical evidence from Ethiopia
}

\author{
Melaku Adinew Ayitehgiza \\ Department of Economics, Dire Dawa University, Dire Dawa, Ethiopia \\ DOI: 10.29322/IJSRP.10.08.2020.p104118 \\ http://dx.doi.org/10.29322/IJSRP.10.08.2020.p104118
}

\begin{abstract}
Carbon dioxide (CO2) emissions are a leading cause of environmental pollution and have been the most significant problems for the worldwide community. This study examines the dynamic causal relationships between $\mathrm{CO} 2$ emissions, industrial structure, economic growth and urbanization for the period 1980 2017 using the Autoregressive Distributed Lag (ARDL) bounds testing approach and Granger causality tests. Augmented DickeyFuller and the Phillips-Perron tests used to examine of unit roots of the variables. The results showed that industrial structure, economic growth and urbanization increases $\mathrm{CO} 2$ emissions. The result of Granger causality test indicated that there is a bidirectional causal relationship between industrial structure, economic growth, and urbanization and $\mathrm{CO} 2$ emissions. The results recommend that industrial structure, economic growth and urbanization were the main determinants of environmental pollution in Ethiopia and a series of policy actions related to industrial structure, economic growth and urbanization should be taken to reduction the environmental degradation.
\end{abstract}

Index Terms- Carbon emissions, economic growth, industrial structure, urbanization, ARDL, Ethiopia

\section{INTRODUCTION}

$\mathrm{H}$ uman-related carbon dioxide emissions appear to be the major source of environmental pollution in the world (IPCC , 2007). An increase of the concentration of the carbon dioxide emission in the atmosphere is one of the most significant problems for the worldwide community. Fossil fuels are main sources of these $\mathrm{CO}_{2}$ emissions uses of in all sectors. Thus, the world community has been able to regulator carbon emissions and deal with the low carbon economy. Some countries, such as Ethiopia has started a national policy design of the climate resilient green economy (CRGE) strategy in 2011 to deal with current as well as future impacts of climate change (FDRE, 2015)

$\mathrm{CO} 2$ emissions have been increased significantly from newly industrialized countries when compared with industrialized countries (Jonathan Woetzel et al., 2019; Munir \& Zhen, 2018). Global warming has reached alarming levels, raising concerns about global warming and climate change (IPCC, 2013). As a result, $\mathrm{CO} 2$ emission and its relationship with economic growth has become important issue in recent years. The effects of

This publication is licensed under Creative Commons Attribution CC BY.

http://dx.doi.org/10.29322/IJSRP.10.08.2020.p104118 economic growth on $\mathrm{CO} 2$ emission have become a common area of research in different disciplines.

The dynamic expansion of urbanization is a phenomenon that tends to increase social and economic ability from the rural areas to urban areas (UN , 2019). The physical expansions of urban areas lead to economic changes in many developing countries. An increase in the number of people living in cities can boost economic growth and increase trade with the rest of the world, which in turn can increase carbon emissions in the economy.

An overview of urbanization reveals flow from rural areas to urban areas associated with factors of economic activities, such as lifestyle, culture and behavior, changing industrial structure, new housing and public facilities and city size distribution(UN, 2019). Urbanization creates upward pressure on $\mathrm{CO} 2$ emissions (Anwar \& Younis, 2020; Frank, 2016; Niu and Lekse, 2017; Zhang et al., 2015).

Urban development provides a great opportunity for industrial development by increasing demand in cities and changing consumer attitudes in African countries(ECA, 2017). Urban expansion and industrial development increase carbon emissions (Arwar \& Lsaggaf, 2019). Based on the perspective of developed and developing countries, many researchers have conducted extensive research on urban emissions and industrial development in terms of CO2 emissions (Ke and Boqiang, 2015; Liu \& Bae, 2018; Munir \& Zhen, 2018; Xu \& Lin, 2015).

Ethiopia's urban population is growing rapidly. According to the Central Statistics Agency, the city's population is estimated to have tripled from 15.2 million in 2012 to 42.3 million in 2037 . This means that it is growing at an annual rate of 3.8 percent (CSA, 2013). Rapid urban expansion can hamper demographic problems to provide jobs, infrastructure, services and housing. Poor management of these issues has challenges with environmental pressures such as $\mathrm{CO} 2$ emissions. As far as I know, there are currently no single study attempted to investigate this relationship or the dynamic impact of urbanization, economic growth, and industrial structure on $\mathrm{CO} 2$ emissions in the existing literature in Ethiopia; therefore, this study contributed to the existing literature by examining the causal linkage between urbanization, economic growth, and industrial structure on $\mathrm{CO} 2$ emissions in Ethiopia.

The rest of the paper is structured as follows. Section 2 refers to literature on the effects of urbanization, industrial structure and economic growth on $\mathrm{CO} 2$ emissions. Section 3 refers the methodology. Section 4 refers the results and discusses of the estimates and Section 5 concludes and policy implications. 


\section{LITERATURE REVIEW}

Several studies have empirically discussed the impacts of urbanization, economic growth, and industrial structure on carbon dioxide emissions in different regions, income levels, and countries. For example, Usama and Ozturk, (2015), used the FMOLS approach in the MENA (Middle East and North African) region during the period 1996 to 2012 and examine the effect of energy consumption, urbanization, trade openness, industrial output, and the political stability on the environmental degradation. The outcome shows that energy consumption, urbanization, trade openness and industrial development increases environmental damage. Also, (Mikayilov et al., 2017) used Autoregressive Distributed Lags Bounds Testing approach based on Azerbaijan economy during 1990 - 2014, and the outcome discloses that on average, urbanization increases carbon emissions as its $1 \%$ upsurge could increase carbon emissions by $2.71 \%$ in the sample countries.

Munir \& Zhen, (2018) examined the linkages among industrialization, urbanization, energy consumption, $\mathrm{CO} 2$ emissions and economic growth a heterogeneous panel study of China from 2000 to 2016. In this study, Augmented Mean Group (AMG) estimator and Common Correlated Effects Mean Group (CCEMG) estimator was used within the analysis. The result of the study urbanization, and industrialization have a positive and statistically significant influence on $\mathrm{CO} 2$ emissions, also a unidirectional causality that run from urbanization and industrialization to $\mathrm{CO} 2$ emissions in both short- and long-term periods.

Ke and Boqiang, (2015) used the regression on population, affluence, and technology (STIRPAT) approach while investigating the influence of Impacts of urbanization and industrialization on energy consumption and $\mathrm{CO} 2$ emissions across 73 economies from 1971-2010, The finding shows that the impact of urbanization influences carbon emissions positively for all income groups. Yansui et al., (2016) based on a panel data of 31 provinces in China over the period 1997-2010, this study empirically examines the determinants of $\mathrm{CO} 2$ emissions. The main finding shows that both urbanization and economic growth increase $\mathrm{CO} 2$ emissions.

Wang et al., (2015) were applied the panel fully modified ordinary least squares technique, and examined the relationship between urbanization, energy use and carbon emissions in different regions of Southeast Asian nations (ASEAN) countries during the period of 1980 to 2009. The findings suggest that urbanization increases carbon emissions, which means a $1 \%$ rise in urban population results in a $0.20 \%$ increase in carbon emissions. Zhang \& Lin, (2012) were used the STIRPAT approach and investigated Panel estimation for urbanization, energy consumption and CO2 emissions in China from 1995 to 2010. The result discloses that urbanization increases residential carbon emissions in the eastern region.

Murat \& Eyyup, (2015) used the Pedroni and Kao cointegration methods and Granger causality test based on vector error correction model (VECM) approach and investigated the nexus among urbanization, energy consumption and $\mathrm{CO} 2$ emissions during 1985 and 2010 in Sub-Saharan countries. The results indicated that urbanization is the main determinants of environmental pollution in these countries. Also, the recent study of Soheila \& Anahita, (2019) examines the dynamic causal relationships between $\mathrm{CO} 2$ emissions, energy consumption, economic growth, trade openness and urbanization from the period 1980 to 2014 employed the pooled mean group approach and panel Granger causality tests for Asian countries. The results showed that urbanization increases $\mathrm{CO} 2$ emissions. Abbasi et al., (2020), study attempts to analyze the influence of urbanization, economic growth, and population size on residential carbon emissions in the South Asian Association for Regional Cooperation (SAARC) member nations for the period 1994 to 2013 employ an augmented STIRPAT model. The empirical results showed that a U-shaped relationship exists between urbanization and residential carbon emissions.

\section{METHODOLOGY}

The purpose of this paper is to explore the impact of urbanization (share of urban population in total population), economic growth (GDP) and industrial structure (share of industry value added in GDP) on $\mathrm{CO} 2$ emissions for Ethiopia. The paper uses annual time series of urbanization, industrial structure, and economic growth impact on carbon dioxide emissions. Carbon dioxide emissions are taken as a dependent variable and urbanization, industrial structure, and economic growth as the main independent variables. The data used for the period of 19812017 from the World Bank of World Development Indicator database. The empirical models can be specified as follows:

$C O_{2 i t}=f\left(U R B_{i t}, I N D U_{i t}, G D P_{i t}\right)$

(1)

The variables are converted into a logarithmic form for better consistency and efficient results and the mathematical form of the model as follows:

$\ln C O_{2 i t}=\beta_{0}+\beta_{1} \ln U R B_{i t}+\beta_{2} \ln I N D U_{i t}+\beta_{3} \ln G D P_{i t}+\varepsilon_{i t}$

(2)

Where $\ln \mathrm{CO} 2$ is the logarithm of carbon dioxide emissions as measured the total carbon emissions divided by GDP measured at constant $2010 \mathrm{USD}, \ln U R B$ is the logarithm of urbanization measured by the percentage of the urban population, who are living in urban regions, in total population, $\ln I N D U$ is the logarithm of the industrial structure measured by industry value added (\% of GDP) and $\ln G D P$ is the logarithm of economic growth measured by the real GDP per capita measured at constant 2010 USD, $\mathrm{t}$ is the time trend and $\varepsilon_{\mathrm{i}}$ is white noise error term. The parameters $\beta i$ 's are the long-run elasticity's of $\mathrm{CO} 2$ with respect to urbanization, industrial structure, and economic growth, respectively.

The Autoregressive Distributed Lag (ARDL) bounds testing approach employed to explore the long-run and short-run relationship between $\mathrm{CO} 2$ emission, urbanization, industrial structure, and economic growth. The ARDL model evaluated that the calculated F-statistic value with the critical values developed by Pesaran, Shin and Smith (2001). In the study by Pesaran, Shin and Smith (2001), the lower bound critical values variables are integrated at order zero and the upper bound critical values of variables are integrated at order one. If the computed F-statistic is smaller than the lower bound value, then the null hypothesis is not rejected and there is no long-run relationship between among the variables. The mathematical demonstrations of the ARDL approach as follows: 
$\Delta \ln C o_{2 t}=\beta_{0}+\beta_{2} \ln C O_{2 t-i}+\beta_{2} \ln U R B_{t-i}+\beta_{3} \ln I N D U_{t-i}+$

$\beta_{4} \ln G D P_{t-i}+\sum_{i=1}^{p_{1}} \rho_{1} \Delta \ln C o_{2 t-i}+\sum_{i=1}^{p_{2}} \rho_{2} \ln U R B_{t-i}+$

$\sum_{i-1}^{p_{3}} \rho_{3} \ln I N D U_{t-i}+\sum_{i-1}^{p_{4}} \rho_{4} \ln G D P_{t-i}+\varepsilon_{t}$

Where $\Delta$ represents change, $\mathrm{p}$ is the optimum lag lengths and $\varepsilon_{\mathrm{t}}$ is the residual term. The existence of the co-integration relationship between variables from the above equation is investigated by testing the significance of the lagged levels of variables using the F-statistic or Wald-coefficient test. The null hypothesis can be tested is Ho: $\rho 1=\rho 2=\rho 3=\rho 4=0$ and alternative hypothesis $\mathrm{H} 1: \quad \rho 1 \neq \rho 2 \neq \rho 3 \neq \rho 4 \neq 0$. This can determine the long-term relationship between the study variables based on the calculated F-value. The calculated F-value greater than the upper bound critical value, reject the null hypothesis. The error correction model estimate for short-term relationships is used in the ARDL test approach. The ARDL Bound testing approach is given by the following equations.

$\Delta \operatorname{lnC} o_{2 t}=\rho_{0}+\sum_{i=1}^{p_{1}} \rho_{1} \Delta \ln C o_{2 t-i}+\sum_{i=1}^{p_{2}} \rho_{2} \ln U R B_{t-i}+$ $\sum_{i-1}^{p_{3}} \rho_{3} \ln I N D U_{t-i}+\sum_{i-1}^{p_{4}} \rho_{4} \ln G D P_{t-i}+\delta E C M_{T-i}+\varepsilon_{t}$
Where ECM (-1) term is a lagged value of the error correction term of model in which the long-term relationship is obtained. ECM (1 ) is the speed of adjustment of parameter which is to be negative and significant.

\section{RESULTS AND DISCUSSION}

\subsection{Results of unit root test}

A unit root test was applied to determine the integration among the variables. The Augmented Dickey-Fuller,(1979) and the Phillips-Perron,(1988) tests used to examine the existence of unit roots in the variables that are either integrated with $\mathrm{I}(0)$ or I(1). The results of unit roots test of the variables reported on Table 1 .

Table 1: Unit root test

\begin{tabular}{|c|c|c|c|c|c|c|c|c|}
\hline \multicolumn{5}{|l|}{$\mathrm{ADF}$} & \multicolumn{4}{|l|}{$\mathrm{PP}$} \\
\hline & \multicolumn{2}{|l|}{$\mathrm{I}(0)$} & \multicolumn{2}{|l|}{$\mathrm{I}(1)$} & \multicolumn{2}{|l|}{$\mathrm{I}(0)$} & \multicolumn{2}{|l|}{$\mathrm{I}(1)$} \\
\hline Variables & $\mathrm{t}$-value & P-value & $\mathrm{t}$ - value & $\mathrm{P}$-value & $\mathrm{t}$ - value & $\mathrm{P}$-value & $\mathrm{t}$-value & P-value \\
\hline \multicolumn{9}{|l|}{ Intercept } \\
\hline $\operatorname{lnCO} 2$ & 0.449 & 0.9832 & -4.554 & 0.0002 & 0.928 & 0.9934 & -6.263 & 0.0000 \\
\hline $\operatorname{lnGDP}$ & 0.581 & 0.9871 & -5.576 & 0.0000 & 1.188 & 0.9959 & -8.573 & 0.0000 \\
\hline $\ln U R B$ & -0.928 & 0.7786 & -5.749 & 0.0000 & -1.275 & 0.6406 & -4.451 & 0.0002 \\
\hline $\operatorname{lnINDU}$ & -1.005 & 0.7513 & -5.504 & 0.0000 & -0.677 & 0.8527 & -4.269 & 0.0004 \\
\hline \multicolumn{9}{|c|}{ Intercept and Trend } \\
\hline $\operatorname{lnCO} 2$ & -2.51 & 0.323 & -4.679 & 0.0008 & -2.831 & 0.1857 & -6.338 & 0.0000 \\
\hline $\operatorname{lnGDP}$ & -0.816 & 0.9643 & -5.468 & 0.0000 & -0.436 & 0.9857 & -8.429 & 0.0000 \\
\hline $\ln U R B$ & -1.837 & 0.6868 & -5.651 & 0.0000 & -1.636 & 0.778 & -4.371 & 0.0024 \\
\hline $\operatorname{lnINDU}$ & -1.899 & 0.6554 & -5.51 & 0.0000 & -1.568 & 0.8047 & -4.386 & 0.0023 \\
\hline
\end{tabular}

ADF tests with intercept and with intercept and trend $1 \%$ and level of significance

As seen in the above in Table (1), all variables are nonstationary at level, but all variables are stationary at first difference. This implies that the existence of non-stationary of the null hypothesis has been rejected at $1 \%$ level of significance.

\subsection{ARDL bounds test approach to co-integration}

The results of the unit root test indicate the co-integration between the variables estimates. The ARDL bounds test used to examine co-integration long run and short-run relationships between the variables using F-statistics.

Table 2: ARDL bounds test

$\begin{array}{lll}\text { Test Statistic } & \text { Value } & \mathrm{k}^{*} \\ \text { F-statistic } & 7.194 & 3 \\ \text { Critical Value Bounds } & & \\ \text { Significance } & \text { I0 Bound } & \text { I1 Bound }\end{array}$




\begin{tabular}{llc}
$10 \%$ & 2.72 & 3.77 \\
$5 \%$ & 3.23 & 4.35 \\
$2.50 \%$ & 3.69 & 4.89 \\
$1 \%$ & 4.29 & 5.61 \\
\hline
\end{tabular}

The F-statistic tests the null hypothesis of no co-integration

The results of Table (2) to verify the existence of co-integrated among the variables; the value of the F- statistics test is more than the upper value of critical value at $1 \%, 5 \%$ and $10 \%$ respectively. Therefore, reject the null hypothesis of no co-integrated among the studying variables. The existence of co-integrated among the studying variables, the next step is to estimate the long-run and short -run ARDL.

\subsection{Long-run and short -run ARDL estimation results}

The long-run ARDL estimation results reported on Table 3 below. The coefficient of the economic growth has a positive and statistically significant at a 5 percent level in long-run. This means one percent increases in the economic growth that predicted to increases the $\mathrm{CO} 2$ emission by 11.56 percent in the long run. This result is consistent with the findings of Khoshnevis Yazdi \& Dariani, (2019); Asim, Mustafa and Inayat, (2020); Hanif, (2018); Yansui et al., (2016) Shaojian, Guangdong and Chuanglin,
(2017). Agricultural economy the country is a major contributor to carbon dioxide and it plays an important role in exporting carbon dioxide to the world.

The coefficient of urbanization has a positive and significant effect at $1 \%$ level on carbon dioxide emission. This is indicative, a $1 \%$ increase in the percentage of the urban population cause to 110.6 $\%$ increase in carbon emission. Khoshnevis Yazdi \& Dariani (2019) ;Ponce \& Marshall, (2014); Niu \& Lekse, (2018); Asim, Mustafa and Inayat, (2020); Hanif, (2018); Yansui et al., (2016) ; Shaojian, Guangdong and Chuanglin, (2017); Al-Mulali \& Ozturk, (2015); Liu \& Bae, (2018) point out that urbanization is positively correlated with $\mathrm{CO} 2$ emissions.

The coefficient of industry value added is positive and statistically significant at $1 \%$ level on carbon dioxide emission. This implies that an increase of $1 \%$ in industry value-added, it will cause of $31.02 \%$ in $\mathrm{CO} 2$ emissions in the long run. This result is consistent with various studies that examine such relationship of Al-Mulali \& Ozturk, (2015; Asumadu-Sarkodie \& Owusu, (2017; Cherniwchan, 2012; Liu \& Bae, (2018).

Table 3: Long-run ARDL results

\begin{tabular}{|c|c|c|c|c|}
\hline Variables & Coefficients & Std. Error & t-Statistic & Probability \\
\hline $\operatorname{lnGDP}$ & 0.1156259 & 0.0442533 & 2.61 & $0.014^{*}$ \\
\hline $\operatorname{lnURB}$ & 1.105993 & 0.0680279 & 16.26 & $0.000^{* *}$ \\
\hline $\operatorname{lnINDU}$ & 0.3102311 & 0.105222 & 2.95 & $0.006^{* *}$ \\
\hline \multicolumn{5}{|c|}{ Short -run ARDL results } \\
\hline Variables & Coefficients & Std. Error & t-Statistic & Probability \\
\hline $\operatorname{lnGDP}$ & 0.5369331 & 0.1167403 & 4.6 & $0.0000^{*}$ \\
\hline $\ln U R B$ & 0.749462 & 0.148057 & 5.06 & $0.0000^{*}$ \\
\hline $\operatorname{lnINDU}$ & 0.4210006 & 0.1119977 & 0.76 & $0.0001 *$ \\
\hline $\operatorname{ECT}(-1)$ & -0.6776372 & 0.1403059 & -4.83 & $0.0000^{*}$ \\
\hline
\end{tabular}

The coefficient of ECM was negative and statistically significant at $1 \%$ level. This means that there is the existence of a long-run causality relationship from $\mathrm{CO} 2$ to economic growth, urbanization and industry value-added. The coefficient of ECM was implies that about $67.76 \%$ of the disequilibrium in $\mathrm{CO} 2$ of the previous year's shock adjusted back to the long-run equilibrium in the current year.

\subsection{Diagnostic test of the ARDL model}

Diagnostic tests incorporate Heteroskedasticity Test, Breusch-Godfrey Serial Correlation LM Test, Jarque-Bera Test, and Ramsey RESET Test. The ARDL of Heteroskedasticity was estimated by ARCH LM Test statistic. The results showed that the null hypothesis of no heteroskedasticity cannot reject at the 5\% significance level. The ARDL of serial correlation was estimated by the Breusch-Godfrey Serial Correlation LM Test statistic. The estimated result indicates that the null hypothesis of no serial correlation cannot be rejected at the 5\% significance level. This means, no serial correlation exists. ARDL of functional misspecification was estimated by the Ramsey RESET test statistic. The result shows that the null hypothesis of functional form cannot be rejected at the 5\% significance level. This means, there is the ARDL model in its specification form. ARDL of normal distribution was estimated by the Jarque-Bera test statistic. The result shows that the null hypothesis of the normal distribution cannot be rejected at the $5 \%$ significance level. This indicated that the residuals are normally distributed. 
Table 5: Diagnostics of the ARDL Model

\begin{tabular}{lll}
\hline Diagnostic Test Statistics & Chi-Square & Probability \\
\hline LM test for autoregressive conditional heteroskedasticity (ARCH) & 0.606 & 0.4364 \\
Ramsey RESET Test & 1.87 & 0.16 \\
Breusch-Pagan / Cook-Weisberg test for heteroskedasticity & 1.37 & 0.241 \\
Breusch-Godfrey LM test for autocorrelation & 0.256 & 0.6128 \\
Jarque-Bera Test for normal distribution & & \\
$\operatorname{lnCO} 2$ & 0.308 & 0.85719 \\
$\operatorname{lnGDP}$ & 1.555 & 0.45963 \\
$\operatorname{lnURB}$ & 0.748 & 0.68799 \\
$\operatorname{lnINDU}$ & 0.783 & 0.67594 \\
Joint & 3.394 & 0.90725 \\
\hline
\end{tabular}

\subsection{Granger-causality test results}

The results of the ARDL estimation for Granger Causality tests were reported on Table 5. The null hypotheses $\operatorname{lnGDP}$ does not Granger Cause $\operatorname{lnCO}_{2}$, lnURB does not Granger Cause $\operatorname{lnCO} 2$ and lnINDU does not Granger Cause $\operatorname{lnCO}_{2}, \operatorname{lnCO}_{2}$ does not Granger Cause lnGDP, lnURB does not Granger Cause lnGDP, lnGDP does not Granger Cause lnURB, InINDU does not Granger Cause $\ln U R B, \operatorname{lnCO}_{2}$ does not Granger Cause $\operatorname{lnINDU}$, lnGDP does not Granger Cause lnINDU and lnURB does not Granger Cause lnINDU reject at 5\% significant level. Therefore, there is a causal relationship carbon dioxide to economic growth, urbanization and industry value added by the chi-square test statistic. The result indicated that there is bi-causal relationship carbon dioxide, economic growth, urbanization, and industry value and unidirectional Granger causality industry value and economic growth and urbanization $\mathrm{CO}_{2}$ emissions in Ethiopia.

Table 5: Granger-causality tests results

\begin{tabular}{|c|c|c|}
\hline Null Hypothesis: & $\chi^{2}$ & If the plots of statistics tests within the critical value at $5 \%$ \\
\hline $\operatorname{lnGDP}$ does not Granger Cause $\operatorname{lnCO} 2$ & 21.474 & are stable and canbot be* rejected. Figures (1) and (2), the plots of \\
\hline lnURB does not Granger Cause $\operatorname{lnCO} 2$ & 15.605 & CUSUM and CUS6OASQ statistics lies within 5\% critical bound \\
\hline lnINDU does not Granger Cause $\operatorname{lnCO} 2$ & 21.923 & are lies in the boundaries and confirm the long-run coefficients \\
\hline $\operatorname{lnCO} 2$ does not Granger Cause lnGDP & 12.673 & stability of the modea.7* \\
\hline
\end{tabular}

* and ** rejection of the null hypothesis at 5\% and $1 \%$ significance level respectively.

\subsection{The stability testing of the ARDL model}

The structural stability of parameter of the ARDL model in the long-run by used the Cumulative Sum (CUSUM) and Cumulative Sum of Square (CUSUMSQ) of residual test for structural stability suggested by Pesaran, Shin and Smith, (2001). If the plots of statistics tests within the critical value at $5 \%$ regression coefficients are stable and caronof be"rejected. Figures (1) and (2), the plots of CUSUM and CUS66\%\$SQ statistics lies within 5\% critical bound for the period. Thus, he plots of the CUSUM and the CUSUMQ stability of the moded.7* 


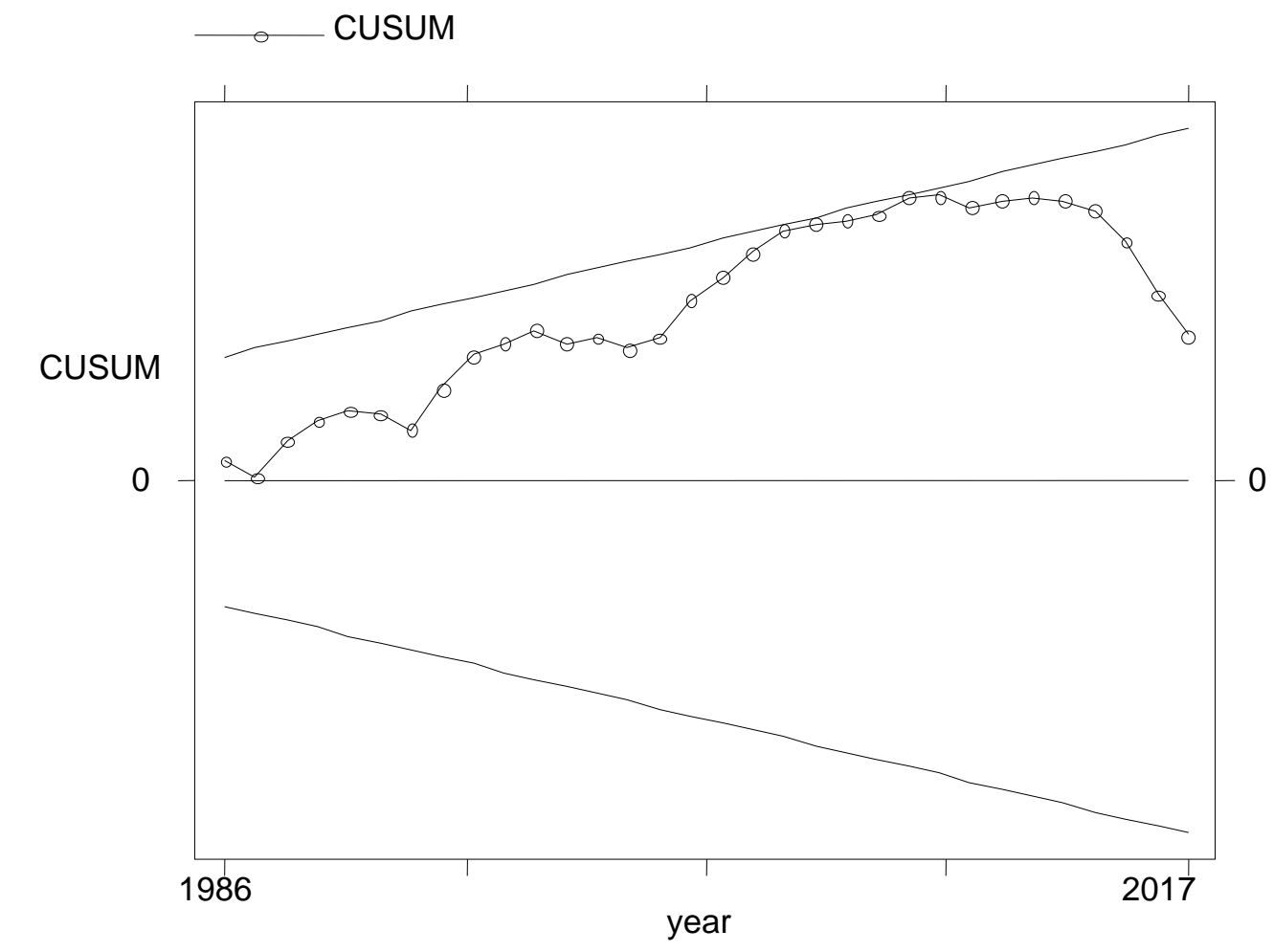

Figure 1: Plots of CUSUM statistics for stability test

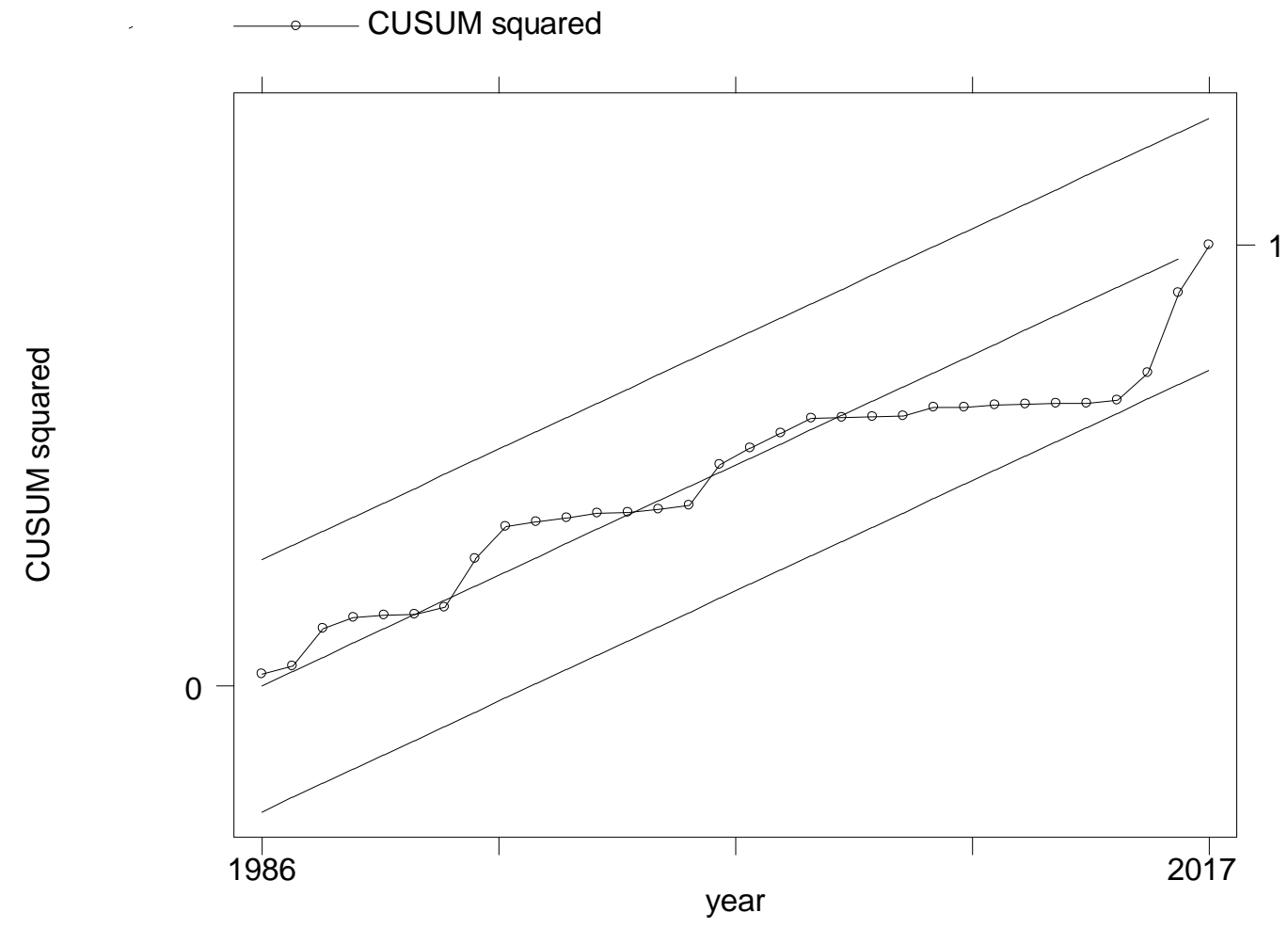

Figure 2: Plots of CUSUMQ statistics for stability test 


\section{CONCLUSIONS AND IMPLICATIONS FOR POLICY}

This study investigated the causal relationship between industrial structure, urbanization, economic growth and $\mathrm{CO}_{2}$ emissions in Ethiopia using ARDL approach for the period 1980 2017. ARDL methods to co-integration were applied. The result of this study showed that industrial structure, urbanization and economic growth are effect on $\mathrm{CO} 2$ emission. Industrial structure, urbanization and economic growth are increasing of $\mathrm{CO} 2$ emission. This implies that the important factors of $\mathrm{CO} 2$ emissions in Ethiopia are industrial structure, urbanization and economic growth.

Furthermore, the study also used the Granger causality test to examine the dynamic causal relations between the studying variables. The results of co-integration test showed that the existences of long- run relationship among the Industrial structure, urbanization, economic growth and $\mathrm{CO}_{2}$ emissions. The results of Granger causality test were a bi-directional Granger causality among industry value, urbanization, economic growth and carbon dioxide. In addition, the results indicate that there is a unidirectional Granger causality industry value and economic growth and urbanization $\mathrm{CO}_{2}$ emissions. The empirical evidence showed that industry value, urbanization and economic growth are the key determinants $\mathrm{CO}_{2}$ emissions Ethiopia. In order to reduction of environmental pollution or $\mathrm{CO}_{2}$ emissions, a series action should implements by policymakers. They may develop effective urbanization plan to decline $\mathrm{CO}_{2}$ emissions or improve environmental quality. They may improve more effective new policies that emphasis the structure of industry value and economic activities that to consider environmental quality.

\section{REFERENCES}

[1] Abbasi, M. A., Parveen, S., Khan, S., Kamal, M. A., \& Kamal, M. A. (2020). Urbanization and energy consumption effects on carbon dioxide emissions : evidence from Asian-8 countries using panel data analysis.

[2] Al-Mulali, U., \& Ozturk, I. (2015). The effect of energy consumption, urbanization, trade openness, industrial output, and the political stability on the environmental degradation in the MENA (Middle East and North African) region. Energy, 84, 382-389. https://doi.org/10.1016/j.energy.2015.03.004

[3] Arwar, S., \& Lsaggaf, A. (2019). ROLE OF URBANIZATION AND URBAN INCOME IN CARBON EMISSIONS : REGIONAL ANALYSIS OF CHINA. 17(2015), 10303-10311.

[4] Asim Anwar, M. Y. and I. U. (2020). Impact of Urbanization and Economic Growth on CO 2 Emission : A Case of Far East Asian Countries. International Journal of Environmental Research and Public Health, Int. J. En.

[5] Asumadu-Sarkodie, S., \& Owusu, P. A. (2017). Carbon dioxide emissions, GDP per capita, industrialization and population: An evidence from Rwanda. Environmental Engineering Research, 22(1), 116-124. https://doi.org/10.4491/eer.2016.097

[6] Cherniwchan, J. (2012). Economic growth, industrialization, and the environment. Resource and Energy Economics, 34(4), 442-467. https://doi.org/10.1016/j.reseneeco.2012.04.004

[7] CSA (Central Statistical Agency). (2013). Population Projection of Ethiopia, 2014-2017. Adiss Ababa, Ethiopia.

[8] Dickey, D. A., \& Fuller, W. A. (1979). Distribution of the Estimators for Autoregressive Time Series With a Unit Root. 74(366), 427-431.

[9] ECA(Economic Commission for Africa). (2017). Economic Report on Africa 2017: Urbanization and Industrialization for Africa's Transformation.

[10] Frank, A. (2016). CARBON DIOXIDE EMISSIONS , URBANIZATION AND POPULATION: EMPIRICAL EVIDENCE IN SUB SAHARAN AFRICA Keywords: Contribution / Originality. 3(1), 1-16. https://doi.org/10.18488/journal.82/2016.3.1/82.1.1.16
[11] Hanif, I. (2018). Impact of economic growth, nonrenewable and renewable energy consumption, and urbanization on carbon emissions in Sub-Saharan Africa.

[12] IPCC. (2013). CLIMATE CHANGE 2013: The Physical Science Basis. Contribution of Working Group I to the Fifth Assessment Report of the Intergovernmental Panel on Climate Change [Stocker, T.F., D. Qin, G.-K. Plattner, M. Tignor, S.K. Allen, J. Boschung, A. Nauels, Y. Xia,

[13] IPCC (Intergovernmental Panel on Climate Change). (2007). Climate change 2007: the physical science basis of climate change, contribution of working group I to the fourth assessment report of the Intergovernmental Panel on Climate Change.

[14] Jonathan Woetzel, S., Jeongmin Seong, S., Nick Leung, H. K., Joe Ngai, H K., James Manyika, S. F., Anu Madgavkar, M., Susan Lund, Washington, D., \& Andrey Mironenko, S. (2019). China and the world: Inside the dynamics of a changing relationship;McKinsey Global Institute; www.mckinsey.com/mgi. July.

[15] Ke Li and Boqiang Lin. (2015). Impacts of urbanization and industrialization on energy consumption / CO 2 emissions : Does the level of development matter? Renewable and Sustainable Energy Reviews, 52, 1107-1122. https://doi.org/10.1016/j.rser.2015.07.185

[16] Khoshnevis Yazdi, S., \& Dariani, A. G. (2019). CO2 emissions, urbanisation and economic growth: evidence from Asian countries. Economic Research$\begin{array}{llll}\text { Ekonomska Istrazivanja 310-530. } & \text { 32(1), }\end{array}$ https://doi.org/10.1080/1331677X.2018.1556107

[17] Lekse, H. N. and W. (2017). Carbon emission effect of urbanization at regional level: empirical evidence from China. Economics Discussion Papers, No 2017-62, Kiel Institute for the World Economy. Http://Www.Economics- Ejournal.Org/Economics/Discussionpapers/201762 Received.

[18] Liu, X., \& Bae, J. (2018). Urbanization and industrialization impact of CO 2 emissions in China. Journal of Cleaner Production Journal, 172, 178-180.

[19] Mikayilov, J., Shukurov, V., \& Mukhtarov, S. (2017). Does Urbanization Boost Pollution from Transport? Acta Universitatis Agriculturae et Silviculturae Mendelianae Brunensis, 65, 1709-1718. https://doi.org/10.11118/actaun201765051709

[20] Munir Ahmad \& Zhen-Yu Zhao. (2018). Empirics on linkages among industrialization, urbanization, energy consumption, $\mathrm{CO} 2$ emissions and economic growth: a heterogeneous panel study of China. Environmental Science and Pollution Research;Https://Doi.Org/10.1007/S11356-018-30543.

[21] Murat Çetin \& Eyyup Ecevit. (2015). Urbanization , Energy Consumption and CO 2 Emissions in Sub-Saharan Countries: A Panel Cointegration and Causality Analysis Associate Professor Murat Cetin 1 \& Associate Professor Eyyup Ecevit 2. 3(2), 66-76. https://doi.org/10.15640/jeds.v3n2a7

[22] Niu, H., \& Lekse, W. (2018). Carbon emission effect of urbanization at regional level: empirical evidence from China. Economics: The OpenAccess, Open-Assessment $\quad$ E-Journal, 2017. https://doi.org/10.5018/economics-ejournal.ja.2018-44

[23] Pesaran, M.H., Shin, Y. and Smith, R. . (2001). Bounds testing approaches to the analysis of level relationship. Journal of Applied Economics, 16, 289326. https://doi.org/10.3390/economies6010002

[24] Phillips Peter C. B and Pierre, P. (1988). Testing for a unit root in time series regression. Biometrika, 75(2), 335-346.

[25] Ponce De Leon Barido, D., \& Marshall, J. D. (2014). Relationship between urbanization and $\mathrm{CO} 2$ emissions depends on income level and policy. Environmental Science and Technology, 48(7), 3632-3639. https://doi.org/10.1021/es405117n

[26] Shaojian Wanga, G. L. and C. F. (2017). Urbanization, economic growth, energy consumption, and $\mathrm{CO} 2$ emissions Empirical evidence from countries with different income levels).pdf.

[27] Strategy, C. R. (n.d.). Ethiopia 's Climate Resilient Green Economy CLIMATE RESILIENCE STRATEGY.

[28] UN(United Nations). (2019). Department of Economic and Social Affairs, Population Division. World Urbanization Prospects: The 2018 Revision (ST/ESA/SER.A/420). New York: United Nations.

[29] Usama Al-Mulali and Ilhan Ozturk. (2015). The effect of energy consumption , urbanization, trade openness, industrial output , and the political stability on the environmental degradation in the MENA ( Middle East and North African ) region. Energy, 84, 382-389. https://doi.org/10.1016/j.energy.2015.03.004 
[30] Wang, Y., Chen, L., \& Kubota, J. (2015). The relationship between urbanization, energy use and carbon emissions : evidence from a panel of Association of Southeast Asian Nations ( ASEAN ) countries. Journal of Cleaner Production, 1-7. https://doi.org/10.1016/j.jclepro.2015.06.041

[31] Xu, B., \& Lin, B. (2015). How industrialization and urbanization process impacts on $\mathrm{CO} 2$ emissions in China: Evidence from nonparametric additive regression models. Energy Economics. https://doi.org/10.1016/j.eneco.2015.01.005

[32] Yansui, L. I. U., Bin, Y. A. N., \& Yang, Z. (2016). Urbanization, economic growth, and carbon dioxide emissions in China: A panel cointegration and causality analysis. 26(15), 131-152. https://doi.org/10.1007/s11442-016$1259-2$
[33] Zhang, C., \& Lin, Y. (2012). Panel estimation for urbanization , energy consumption and CO 2 emissions: A regional analysis in China. Energy Policy, 49, 488-498. https://doi.org/10.1016/j.enpol.2012.06.048

[34] Zhang, Y., Yi, W., \& Li, B. (2015). The impact of urbanization on carbon emission : empirical evidence in Beijing. Energy Procedia, 75, 2963-2968. https://doi.org/10.1016/j.egypro.2015.07.601

\section{AUTHORS}

First Author - Melaku Adinew Ayitehgiza, Department of Economics, Dire Dawa University, Dire Dawa, Ethiopia 